Journal of Economics and Behavioral Studies

Vol. 6, No. 6, pp. 432-437, June 2014 (ISSN: 2220-6140)

\title{
The Enhancement of Conference Tourism activities as a means to Bolstering Business Tourism in South Africa: A Case Study of Conferences within KwaZulu-Natal, South Africa
}

\author{
*Wayne B. Tifflin, R. Balkaran \\ Durban University of Technology, South Africa \\ *wayne@zulu.org.za
}

\begin{abstract}
Business Tourism is considered an important aspect of a Destination's Competitiveness. However having a competitive advantage does not guarantee success (Ritchie and Crouch, 2003). Destination success requires a well formulated competitiveness strategy which is effectively implemented (Seymour, 2009:2). Business tourism and its elements (meeting, conference, and convention centres) need to be managed effectively to provide a destination with a competitive edge. Thus it is important to determine the effectiveness and suitability of conference centres and destinations from the perspective of the delegate. This paper examines the responses of delegate of 49 Conferences in relation to the facilities at the International Convention Centre in Durban, KwaZulu-Natal and the city of Durban as a conference destination. Whilst the broader concept of Business Tourism may encompass more than conferences as a business activity, this paper will show the need for "Conference Tourism" as significant component to Business Tourism. KwaZulu-Natal's meetings and conferences are one of the most important attractions and activities of domestic and international tourists. This is clearly illustrated in the following tables:
\end{abstract}

Keywords: Conference tourism, business tourism, South Africa

\section{Introduction}

Business Tourism is considered an important aspect of a destination's competitiveness. However having a competitive advantage does not guarantee success (Ritchie and Crouch, 2003). In order for a destination to be successful, one of the requirements is to have a well formulated strategy that can be effectively implemented (Seymour, 2009:2). Business tourism and its elements (meeting, conference, and convention centres) need to be managed effectively to provide a destination with a competitive edge. Thus it is important to determine the effectiveness and suitability of conference centres and destinations from the perspective of the delegate. This paper examines the responses of delegate of 49 Conferences in relation to the facilities at the International Convention Centre in Durban, KwaZulu-Natal (KZN) and the city of Durban as a conference destination. KZN's meetings and conferences are one of the more important attractions and activities of domestic and international tourists. This is clearly illustrated were 6.4\%, which equates to approximately 196000 domestic visitors, visit KZN to attend a conference, workshop or a training session TKZN 2008.

This paper will provide a synthesis of the business tourism activities in KwaZulu Natal based on conferences hosted in the province. Recommendations will also be made on ways of enhancing tourism activities through "Conference Tourism".

Activities Undertaken in KZN - Domestic Visitors 2007:

\begin{tabular}{lll}
\hline Activity & Tourists $\mathbf{~} \mathbf{0 0 0}$ & $\mathbf{\%}$ \\
\hline Go to the beach & 2018 & 65.6 \\
Go to a live show, theatre or concert & 593 & 19.3 \\
Watch a live sports event & 567 & 18.4 \\
Visit a museum, art gallery or historical building & 523 & 17.0 \\
Visit a nature or wildlife or game reserve & 498 & 16.2 \\
Take part in a sports event & 449 & 14.6 \\
Take part in any water sport & 449 & 14.6 \\
Visit an arts or craft outlet & 401 & 13 \\
Visit an African township or cultural village on a tour & 330 & 10.7 \\
Food and wine fair & 294 & 9.6 \\
Go hiking or mountain climbing & 280 & 9.1 \\
Bird watching & 245 & 8 \\
Art and crafts festival & 209 & 6.8 \\
\end{tabular}




\begin{tabular}{lll}
\hline Attend a conference, workshop or training session & $\mathbf{1 9 6}$ & $\mathbf{6 . 4}$ \\
Visit a health spa & 163 & 5.3 \\
See bushman paintings & 150 & 4.9 \\
Fly-fishing & 133 & 4.3 \\
Horse riding & 121 & 3.9 \\
Go backpack/hostel travelling & 85 & 2.8 \\
Mountain biking or other cycling & 85 & 2.8 \\
Tour of the battlefields & 72 & 2.4 \\
\hline
\end{tabular}

(TKZN, 2008)

\section{Literature Review}

The UNWTO (2007:1) says a destination must be within one day's return journey, a space with boundaries with tourism services, products, and attractions. The UNWTO (2007:1) goes on to say that within these boundaries the management and branding of the destination takes place. Destination competitiveness is about the ability of a destination to deliver goods and services that when compared to other destinations are seen to or perceived to be better by the tourist (Heath, 2003:7). Competition between tourism destinations has increased and no includes other niche tourism experiences and activities such as business travel, gaming, resort areas, nature-based tourism, festivals and cultural tourism and major-events tourism (Ritchie and Crouch, 2000:2). In order to succeed any destination needs to make sure that their experiences must be equal to or better than its competitive destinations (Dwyer and Kim 2003:1). Dwyer and Kim (2003: 3) assert that the importance of tourists' perceptions of a destination is such they warrant separate recognition in a model of destination competitiveness. Essentially they say that destination competitiveness is about the ability to deliver a full tourist experience that is better and outperforms that of rival destinations. These experiences will be those that the tourist sees as important (2003:3). Dwyer and Kim (2003) measure the competitiveness of a destination by measuring the sustainable well-being of the residents.

Mazanec, WÖber and Zins (2007:87) quote a definition of destination competitiveness by Ritchie and Crouch (2003), which is: "[W] hat makes a tourism destination truly competitive is its ability to increase tourism expenditure, to increasingly attract visitors while providing them with satisfying, memorable experiences, and to do so in a profitable way, while enhancing the well-being of destination residents and preserving the natural capital of the destination for future generations". They assert that this is more than a definition and that this is also an explanation. They contend that the satisfying and memorable experience is an antecedent to increasing tourism arrivals. This paper argues that the experiences of a conference/convention delegate also enhance the image and thus the competitiveness of the destination. Fang (2006: ii) states that studies indicated that the needs of tourists influences the competitiveness of a destination. Thus the quality of the experience offered to tourists is an important aspect of a destinations' competitiveness and can differentiate one destination from another. These aspects include infrastructure, economic and political stability, and access. She claims that there is not much research that examines a destinations' competitiveness from the tourists' perspective (Fang, 2006: ii). In her study Fang (2006: ii) found that tourists' perceptions of a destination's competitiveness is positively influenced by the quality of tourism experience within the destination and prior to arriving at the destination. This study examines the perceptions of conference/convention delegates of the tourist destination of Durban.

There are different types of resources that a destination can use to its advantage. These are divided into inherited or endowed resources and competitive resources (Fang, 2006:35). Inherited resources include the climate, scenery, flora, fauna, etc., while competitive resources can include items such as the tourism infrastructure (hotels, attractions, transport network, etc.), festivals and events, the quality of management, skills of employees, government policy and so on. Fang (2006: 35) further states that a competitive advantage is not only the availability of these resources, but also the ability to make use of them to the advantage of the destination. In order to strengthen the KwaZulu-Natal's competitiveness the KZN Durban Convention Bureau (CVB) was established in 2010. The priority of the CVB is to increase the number of conventions/conferences held in the province. This is done through bidding for conventions/conferences and assisting federations, organizations, and PCO's to provide a successful conference/convention. 


\section{Methodology}

Tourism KwaZulu-Natal (TKZN) is a destination marketing organization (DMO) based in the KwaZuluNatal of South Africa. It is responsible for the marketing and tourism development in the province. Research informs the basis of the marketing and development activities of TKZN. The research unit at TKZN, that is responsible for these surveys have implemented guidelines for the type of conferences that will be surveys. Each conference has to be an international one with a minimum of 500 delegates. Face to face surveys were conducted with delegates at each of the conferences. A probability sample design was used stratified by day. At each conference a minimum of 200 interviews was the target. Research at conferences is still ongoing.

\section{Discussion}

At each conference both domestic and international visitors were interviewed. The total respondents thus are far 2864 international (39\%) and $4460(61 \%)$ domestic respondents. These 49 conferences have had a combined total of about 60000 delegates. In order to attract conferences there needs to be a wide range of accommodation facilities available. Delegates need to have these various options available to them. The respondents stayed predominantly in 3-star (38.25\%) hotel accommodation followed by 4-star $(21.66 \%)$ and then 5-star (15.1\%)) accommodation. Other types of accommodation were also used, such as Budget hotels (9.73\%), Guest Houses (3.64\%), B\&B (3.46\%), VFR (8.31\%) and Other $(2.51 \%)$. The mean length of stay was 5.1 nights. Respondents generally stayed 1.5 nights before, 3.6 nights during and 1.7 nights after a conference. In order to enhance the experience of the delegate at the destination, it is encouraged that visitors explore the destination prior to or after the conference. As indicated above respondents do not seem to spend much time in the destination prior to or after a conference. This is confirmed by the number of respondents who take tours in the destination. About $76 \%$ of the respondents do not take any tours, with $10 \%$ and $14 \%$ taking a pre-and post-tour respectively. In order to determine what attractions are popular with delegates, they are asked which attractions have they visited or intend visiting during their stay. It is clear that most respondents have visited the uShaka Marine Theme Park, followed by Durban's Golden Mile.

\section{Figure 1: Attractions Visited}

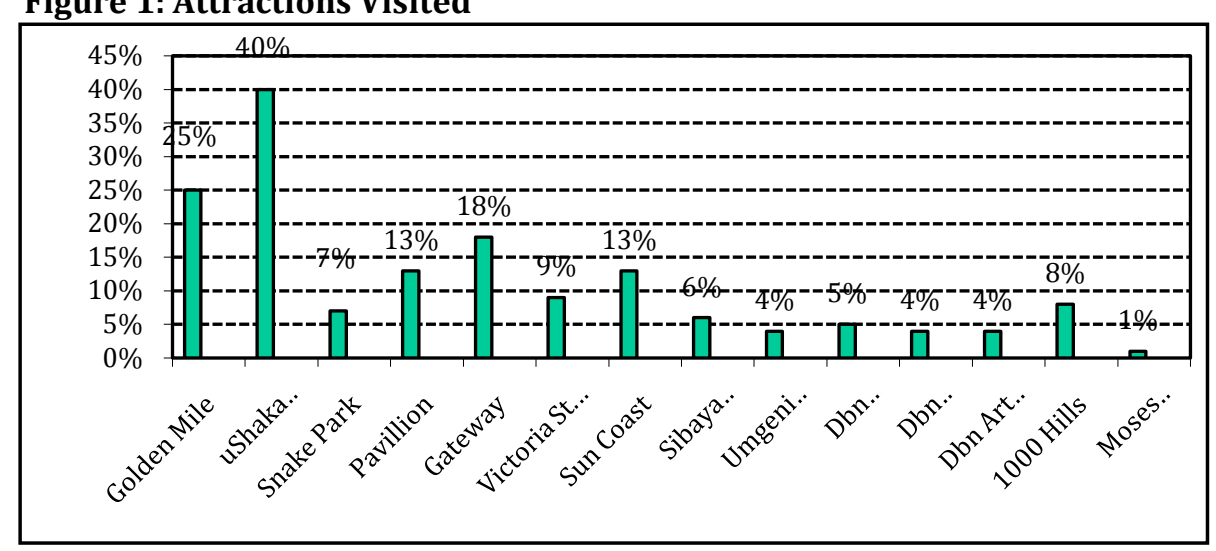

It is important to understand the respondents' perception of the destination thus a number of questions are asked relating to the conferences facility and the destination. The respondents have been asked to rate the Durban as a convention destination. Most rated Durban a very good (38\%), followed by excellent (31\%), followed by good (26\%), then bad (4\%), very bad (3\%) and extremely bad (1\%). Respondents have also been asked to rate Durban as a holiday destination. Most of the delegates rated the destination as very good (39\%), excellent (28\%) and very good (27\%). What is also important is the destination's value for money. Most respondents rated Durban as good (45\%), very good (35\%) and excellent (14\%). It is clear that the respondents rate the destination as a good convention and holiday destination but not as high as a value for money destination. In conjunction with these results respondents were also asked how likely they were to visit Durban in the next five years. About $50 \%$ of the respondents indicated that they were extremely likely to visit Durban again, $36 \%$ possibly and $14 \%$ unlikely. It is however clear that that most of the respondents may be local residents. Respondents were asked what the motivating factor for attending the conference was. On average 73 respondents indicated that the 'opportunity to network with business colleagues' is the most important reason to attend. The 'topics presented at the convention' 
was the second highest rated by respondents. It seems as though the destination is not as important as the networking or topics of the conference. Do other factors, such as access, facilities, prices, in the destination in addition to these two factors increase the competitiveness of the destination? Other factors that were measured were satisfaction levels of convention issues and Durban and surrounds. The responses of the local and international respondents were examined.

Table 1:

\begin{tabular}{ll}
\hline Factor & Average \\
\hline Other & 5 \\
South Africa's shopping & 5 \\
Travel time to Durban & 10 \\
Social events and other arrangements & 7 \\
South Africa's adventure & 8 \\
Low registration costs & 10 \\
Durban \& surrounds as a holiday destination & 10 \\
Sponsorship/ availability of funding & 14 \\
South Africa's beaches & 13 \\
Speaker at/ organizer of convention & 17 \\
South Africa's weather & 16 \\
South Africa as a holiday destination & 18 \\
South Africa's wildlife scenery & 18 \\
South Africa's culture/heritage & 20 \\
Membership of group holding convention & 24 \\
Invited to attend & 40 \\
Employer decision & 42 \\
Topics presented at convention & 57 \\
Opportunity to network with business colleagues & 73 \\
\hline
\end{tabular}

Figure 2: Satisfaction of convention issues

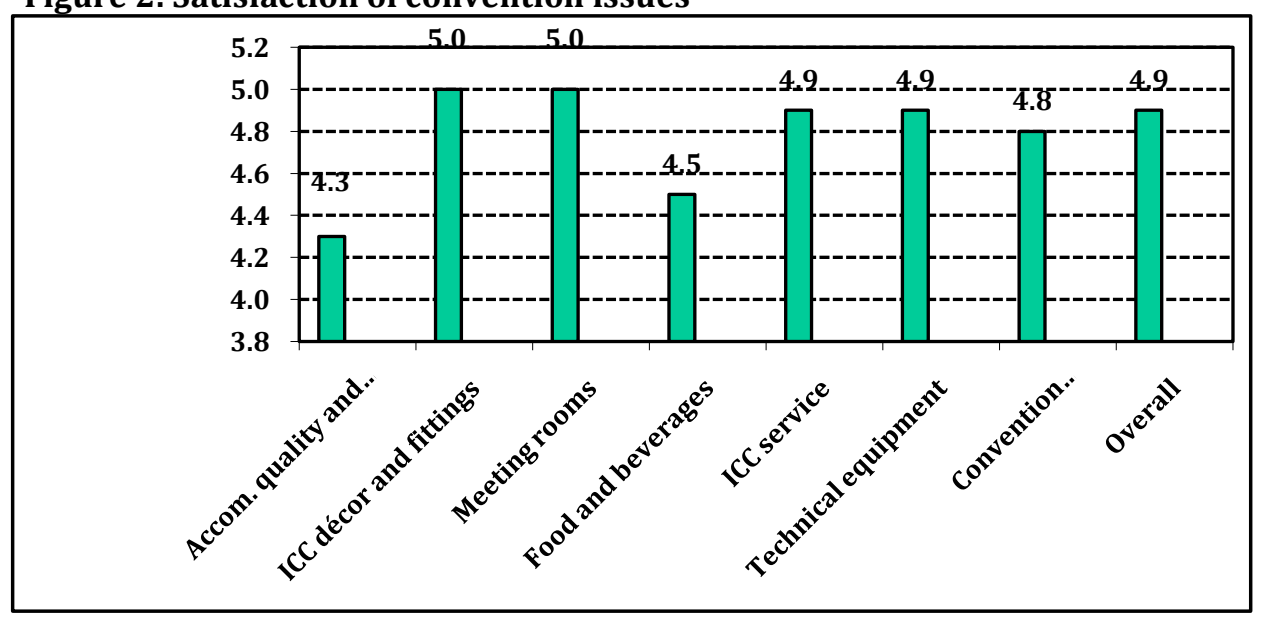

Several aspects were measured in trying to determine the respondents' perception of the convention facility. Therese were accommodation quality and service, International Convention Centre (ICC) decors and fittings, Meetings rooms, food and beverage at the ICC, service at the ICC, technical equipment at the ICC, and the convention programme. A likert scale with 1 representing the lowest rating and 6 representing the highest was used. When taking all the responses into consideration the responses ranged from 4.3 to 5.0. Accommodation quality and services was rated the lowest at 4.3 while the decor and meeting rooms of the ICC was rated the highest at 5.0.

Of the last five conferences the international respondents rated their satisfaction of the convention issues as above. The lowest rating was 4.5 for accommodation quality and service. This was consistent with the overall rating. The ratings by the international delegates were relatively high. It is also important to rate 
the destination. The surveys asked the respondents to rate Durban and surrounds as a convention destination using specific variables using the likert scale with 1 presenting the lowest rating and 6 representing the highest rating. These were:

- Access into Durban and South Africa

- Reception in South Africa

- Safety

- Cleanliness

- Banking

- Public Transport

- Restaurants

- Price of Accommodation

Figure 3: Satisfaction of Convention Issues International delegates

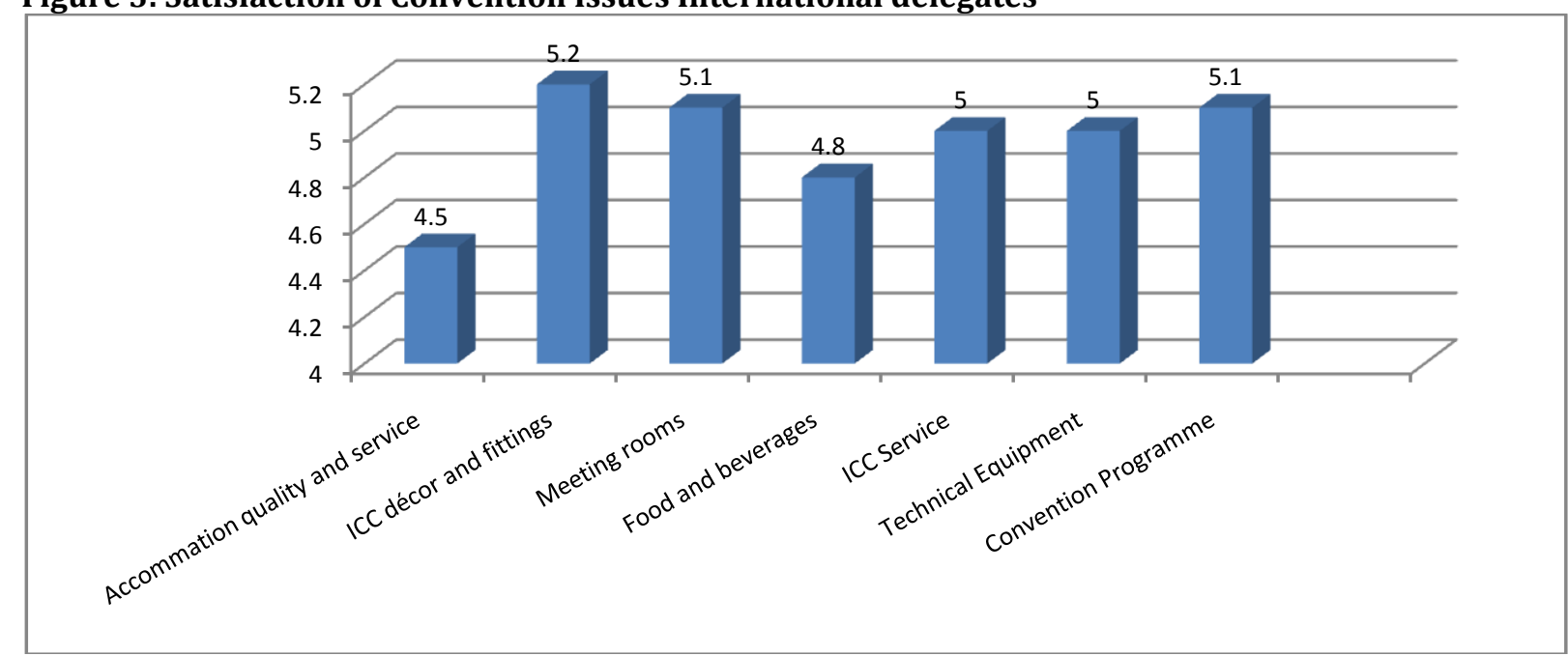

Figure 4: Satisfaction of Durban and Surrounds

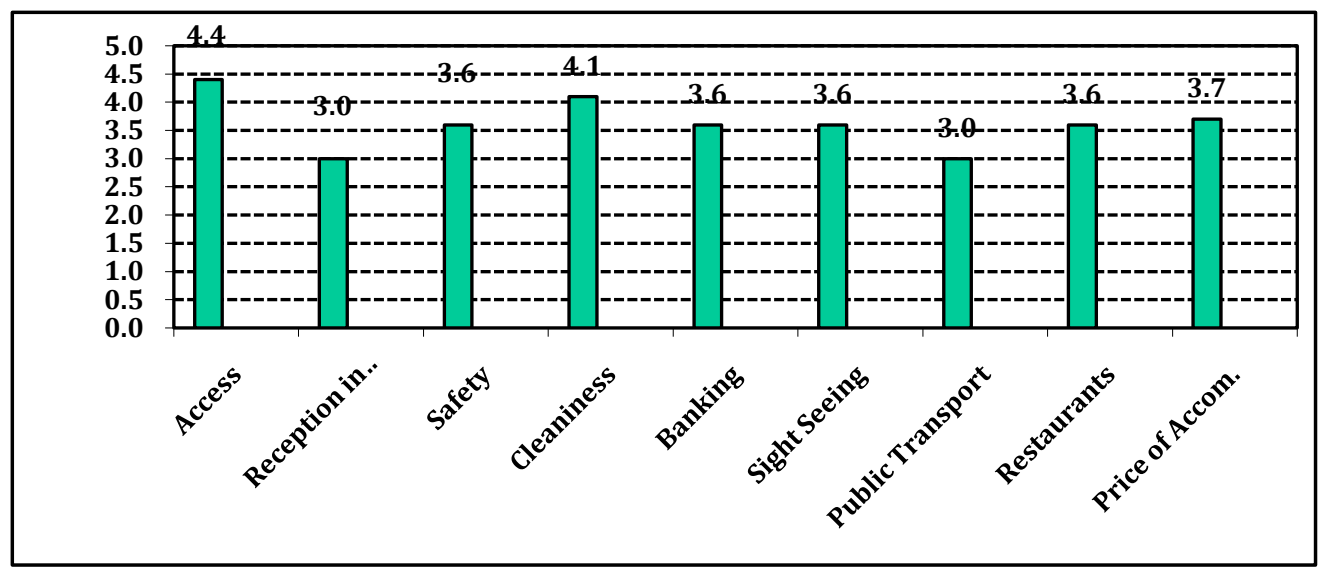

Durban and surrounds were rated as indicated in figure 4 above. The respondents rated their reception into South Africa and the public transport system the lowest. Theses aspects of Durban need to be improved or delegates to convention be made aware of the facilities that are available to them regarding particularly the public transport system. None of the variables were rated above 5 when compared to figure 2 above. Generally there seems to be some improvement necessary in these aspects of the destination. 
Figure 5: Satisfaction of Durban and Surrounds International respondents

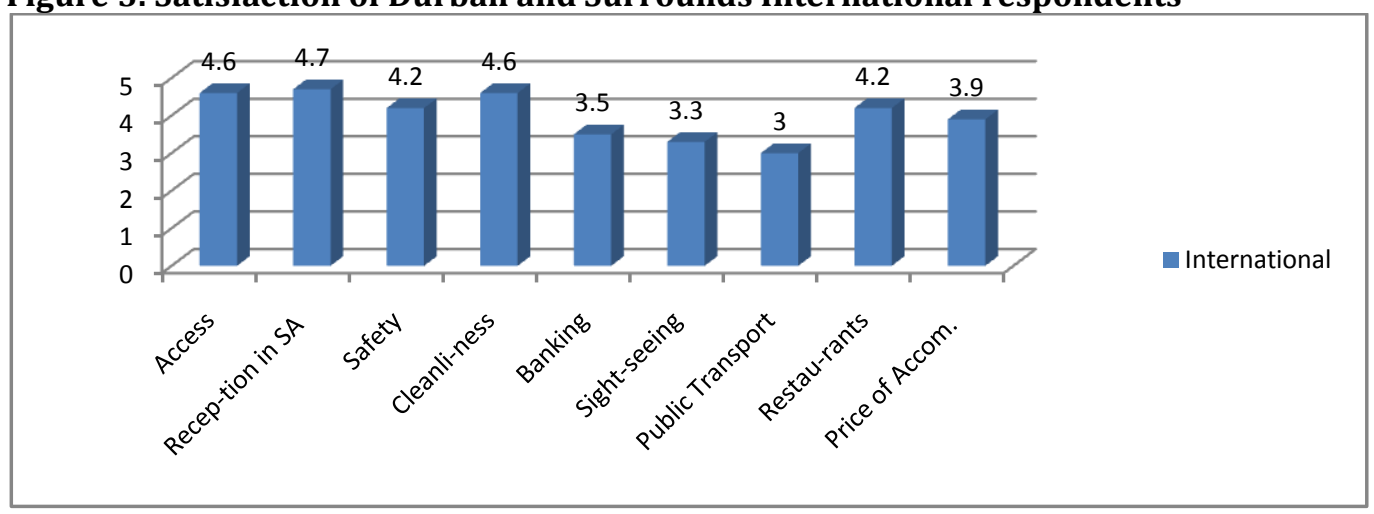

It is clear that the international respondents also rated public transport low. However from a tourism perspective it is concerning that sight-seeing is rated the second lowest. It is important to allow convention delegates to visit the destinations attractions. This will improve their perception of the destination and thus the competitiveness. Banking was also rated low and in this context was access to foreign exchange.

\section{Conclusion}

It is clear that when respondents are asked to rate the destination in general, such as value for money as a holiday destination and as a convention destination, the ratings are above 4 and up to 5 . However when asked to rate the destination according to specific variables the average ratings decline down to the lowest being 3 and the highest less than 5 . Delegates overall perceive the destination to be good in terms of value for money, holiday and a convention destination, but there are some aspects of their experiences that need to be improved as indicated in figures 4 and 5 .

Recommendations: 1 . Provide delegates to conferences and conventions with easy access to discounts to various activities. The conference/convention organizers can also provide discounted access to the theatre that showcase local talent for conference delegates only.

2. The gala dinner of a conference can be held at a venue that provides delegates with an experience of one of the tourist offerings in the destination.

3. Conference organizers, hotels and the local government need to work together to provide transport for delegates who would want to explore the city after the conference hours.

\section{References}

Dwyer, L. \& Kim, C. (2003). Destination Competitiveness: Determinants and Indicators. Current Issues in Tourism, 6(5), 369-44

Fang, M. (2006). En Examination of Destination Competitiveness from a Tourists' Perspective: The Relationship between Quality of Tourism Experience and Perceived Destination Competitiveness. Unpublished $\mathrm{PhD}$ dissertation.

Heath, E. (2003), Towards Model to enhance destination competitiveness: a Southern African perspective

Mazanec, J. A., WÖber, K. \& Zins, A. H. (2007). Tourism Destination Competitiveness: From Definition to Explanation? Journal of Travel Research, 46, 86-95.

Ritchie, J. R. \& Crouch, G. I. (2000). The Competitive Destination: A Sustainable Tourism Perspective. Tourism Management, 21, 1-7

Ritchie, J. R. \& Crouch, G. I. (2003). The Competitive Destination A Sustainable Tourism Perspective Wallington Oxon, UK: CABI International.

Seymour, J. (2009). Tour Operator Marketing Planning and Tourism Competitiveness in KwaZulu-Natal. Unpublished Master of Science dissertation.

Tourism KwaZulu-Natal. (2008). Statistics of our Tourism Sector 2008.

Tourism KwaZulu-Natal (2013). Combined ICC Conference Delegate Survey. Top Line Summary. Power Point Presentation. Unpublished.

UNWTO (2007). Practical Guide to Tourism Destination Management 